\title{
Global Science and the China Split
}

Roger C. Schonfeld

2 ITHAKA S+R 


\section{ITHAKA S+R}

Ithaka S+R provides research and strategic guidance to help the academic and cultural communities serve the public good and navigate economic, demographic, and technological change. Ithaka $\mathrm{S}+\mathrm{R}$ is part of ITHAKA, a not-for-profit organization that works to advance and preserve knowledge and to improve teaching and learning through the use of digital technologies. Artstor, JSTOR, and Portico are also part of ITHAKA.

Copyright 2020 ITHAKA. This work is licensed under a Creative Commons Attribution 4.0 International License. To view a copy of the license, please see https:// creativecommons.org/licenses/by/4.0/.

ITHAKA is interested in disseminating this brief as widely as possible. Please contact us with any questions about using the report: research@ithaka.org. 
The practice of science has always been a fundamentally international activity. Even during periods of substantial geopolitical splits - such as the Cold War-science has broadly continued its international communication and even collaboration. In the post-Cold War period, science has globalized to a substantial degree. However, the looming geopolitical split between China and many of the liberal and democratic nations including Australia, India, J apan, the United Kingdom, and the United States, as well as European Union members, raises questions about what the future may bring. Given the substantial interconnectedness of economies and technology today, there appears to be little prospect of a renewed Cold War or "iron curtain," and science will continue many aspects of its global development. Still, these fast-growing tensions are already causing substantial uncertainty for academic science. This piece examines implications of the developing split on the practice of academic science, with implications for universities, policy makers, learned societies, publishers, and other facilitators of scientific collaboration. ${ }^{1}$

\section{Geopolitical Dynamics}

The geopolitical dynamics underpinning this split have been present for several years, becoming increasingly clear even to an amateur observer of foreign affairs, and I will not try to rehearse a complete history of them here. Suffice it to say that, well before 2020, scholars were writing about how China, as the rising power, and the US, as the reigning power, could avoid war. ${ }^{2}$ This year, the COVID pandemic has unleashed a greater degree of antagonism about motives and intentions into the public sphere than had been seen previously. And it has shown that the split involves far more than just the US, but rather an array of liberal and democratic countries that are, in one way or another, splitting with China. ${ }^{3}$

\footnotetext{
${ }^{1}$ For conversations and reactions that helped me to develop and improve this piece, I thank Bryan Alexander, Danielle Cooper, Elizabeth Sherburn Demers, Joseph Esposito, David Gorvitz, Kevin Guthrie, Catharine Bond Hill, Lisa Janicke Hinchliffe, Kimberly Lutz, Clifford Lynch, Deanna Marcum, Jane Radecki, Oya Rieger, and Christine Wolff-Eisenberg.

${ }^{2}$ Graham T. Allison, Destined for War: Can America and China Escape Thucydides' Trap? Houghton Mifflin Harcourt, 2017. See also this excellent panel discussion about the book, featuring Allison as well as discussants Oriana Skylar Mastro and Roderick MacFarquhar: Michael Szonyi, "Destined for War: Can America and China Escape Thucydides Trap? With Graham Allison," Harvard Fairbank Center for Chinese Studies, n.d., https://podcasts.google.com/feed/aHR0cDovL2ZIZWRzLnNvdW5kY2xvdWQuY29tL3VzZXJzL3NvdW5kY2xvdWQ6dXNIcnM6MTc2 NDc2OTg3L3NvdW5kcy5yc3M/episode/dGFnOnNvdW5kY2xvdWQsMjAxMDp0cmFja3MvNDMONTMyMzU0?ep=14.

${ }^{3}$ To take a few examples: Europeans bristled as Chinese "diplomatic missions started spreading offensive messages against European democracies, sometimes even directly criticizing their handling of the public health crisis" (Philippe Corre and Erik Brattberg, "How the Coronavirus Pandemic Shattered Europe's Illusions of China," Carnegie Endowment for International Peace, July 9, 2020, https://carnegieendowment.org/2020/07/09/how-coronavirus-pandemic-shattered-europe-s-illusions-of-china-pub$\underline{82265}$ ) and the EU has clearly expressed a willingness to stand with the US as opposed to China (Andreas Kluth, "Europe Just Declared Independence From China," Bloomberg Opinion, September 5, 2020,

https://www.bloomberg.com/amp/opinion/articles/2020-09-05/europe-just-declared-independence-from-china and David M. Herszenhorn, "In Global Power Contest, Charles Michel Says EU Takes US Over China," Politico, September 25, 2020, https://www.politico.eu/article/in-global-power-contest-charles-michel-says-eu-takes-us-over-china/);Numerous countries opposed China's actions in Hong Kong (Colin Keatinge, "U.S., U.K., Canada, Others Express 'Deep Concern' Over Hong Kong," Bloomberg, August 9, 2020, https://www.bloomberg.com/news/articles/2020-08-09/u-s-u-k-canada-others-express-deep-concern-over-hongkong); and China and India came to blows militarily in the Himalayas with consequences that included a bifurcation on apps and data (Wikipedia, "2020 China - India Skirmishes," https://en.wikipedia.org/wiki/2020 China\%E2\%80\%93India skirmishes and Maria Abi-Habib, "India Bans Nearly 60 Chinese Apps, Including TikTok and WeChat," The New York Times, June 29, 2020,
} 
These broad shifts in tone and strategy regarding China are present across an array of democratic and liberal countries. In the United States, there is more bipartisan agreement on issues related to China than on many other issues. Should there be a change of government in January 2021, it is clear from the rhetoric of the Biden campaign itself and that of senior Democrats likely to play a role in a new administration that, while there would be important changes in style and substance, many elements of policy will remain the same. ${ }^{4}$

\section{Scientific Openness and Collaboration}

As tensions grow and elements of a split emerge, the impacts on how science is practiced are becoming more clear. The impacts will potentially threaten some aspects of scientific openness, the growing open science movement, international collaboration, and scientific migration.

Scientific openness-the practice of sharing scientific findings broadly-enables the exchange and critique through which theories and experiments become accepted as part of the body of scientific knowledge. Scientific openness drives efficiency by avoiding unnecessary duplication of effort and enables research collaboration. Scientific openness fosters public trust. At the same time, secrecy can also be important to protect research subjects, trade secrets, national security, or other interests. ${ }^{5}$

Maximizing scientific openness, within some limits, has been the accepted standard of practice in many countries for some time. Basic research is conducted for the purpose of understanding science and is rarely monetizable, so it is generally seen as a public good and is much more likely to be governmentally funded than is applied research. Basic research can therefore be practiced with maximum openness.

Consistent with this approach, many funding agencies and policy makers have embraced the open science movement, which calls for making not only the findings of scientific research (such as a publication) but also a variety of intermediate artifacts available for open public inspection. While not yet fully or universally practiced, open science, encompassing initiatives such as open access and open data, is a growing movement. ${ }^{6}$

\footnotetext{
https://www.nytimes.com/2020/06/29/world/asia/tik-tok-banned-india-china.html). It is important to emphasize that, at least to this point, these countries have not organized themselves into an alliance or a bloc.

${ }^{4}$ See for example: Amitai Etzioni, "Bidens Joins the Anti-China Chorus," The Diplomat, August 24, 2020, https://thediplomat.com/2020/08/biden-joins-the-anti-china-chorus/.; What's Biden's New China Policy? It Looks a Lot Like Trump's Jacob M. Schlesinger, "What's Biden's New China Policy? It Looks a Lot Like Trump's," The Wall Street Journal, September 10, 2020, https://www.wsj.com/articles/whats-bidens-china-policy-it-looks-a-lot-like-trumps-11599759286.; Michèle A. Flournoy, "How to Prevent a War in Asia," Foreign Affairs, June 18, 2020, https://www.foreignaffairs.com/articles/united-states/2020-06-18/howprevent-war-asia. Gideon Rachman, "A New Cold War: Trump, Xi and the Escalating US-China Confrontation," Financial Times, October 5, 2020, https://www.ft.com/content/7b809c6a-f733-46f5-a312-9152aed28172; Demetri Sevastopulo, "'This Is a Guy Who Is a Thug': How US Elite Became Hawks on Xi's China," Financial Times, October 8, 2020, https://www.ft.com/content/75ce186e-41f74a9c-bff9-0f502c81e456.

${ }^{5}$ David B. Resnik, "Openness versus Secrecy in Scientific Research" Episteme, 2017, https://doi.org/10.3366/epi.2005.2.3.135.

${ }^{6}$ https://en.wikipedia.org/wiki/Open science
} 
Even while much funding for scientific research is national in character, openness has enabled substantial international collaboration. In recent years, international scientific collaborations have continued to grow, the fruit of sustained efforts of funding agencies and the innate nature of networked societies. ${ }^{7}$ International collaboration has been fostered by policy makers and funding agencies in the US, EU, and elsewhere. ${ }^{8}$

In addition, science is enabled by substantial migration. For example, the US has long benefited by recruiting scholars and students from abroad, encouraging some of the brightest minds to stay permanently. ${ }^{9}$ In recent years, China developed the Thousand Talents program at least in part to encourage many of these individuals to return - and especially talented western researchers to bring their studies to China. ${ }^{10}$

Scientific openness, international collaboration, open science, and scientific migration have been at the heart of much policy and funding among liberal and democratic countries. These policies have enabled a kind of scientific globalism and certainly have offered a powerful form of resistance to scientific nationalism. What might a geopolitical split with China mean for science?

\section{Scientific Tensions}

Even before COVID, the developing split with China was beginning to wash over the academy. Indeed, some government concerns of scientific and industrial espionage by China have probably served to kindle the split. Regardless, academia and scientific research are not somehow immune from these growing geopolitical tensions. As Tobin Smith of the Association of American Universities has said, “I don't think that goes away if Biden is elected...I think Democrat or Republican administration, our stance toward China is changing."11

The underlying concern is that substantial government investments in academic science benefit China in a way that is contrary to the national interest. For example, some analysts have assessed that there are meaningful differences in research funding strategies, with China allocating a much lower share of its R\&D to basic research (10 percent) as opposed to other developed economies (70 percent). They fear that as a result, "China can obtain innovation from the open, global system at low cost and low risk. Then it can dedicate its resources to applying

\footnotetext{
${ }^{7}$ See for example Jeff Grabmeier, "International science collaboration growing at astonishing rate," February 18, 2017, https://phys.org/news/2017-02-international-science-collaboration-astonishing.html. For an effort to quantify and visualize globalization in science, see http://www.globalizationofscience.com/

${ }^{8}$ In some cases, efforts to foster such collaborations reflect at least in part an agenda for "U.S. leadership to shape the global science and engineering agenda." https://www.nsf.gov/od/oise/about.jsp

${ }^{9}$ National Science Board, "Science and Engineering Indicators 2018: Science and Engineering Labor Force," January 2018, https://www.nsf.gov/statistics/2018/nsb20181/report/sections/science-and-engineering-labor-force/immigration-and-the-s-eworkforce.

${ }^{10}$ James Jin Kang, "The Thousand Talents Plan Is Part of China's Long Quest to Become the Global Scientific Leader," The Conversation, August 31, 2020, https://theconversation.com/the-thousand-talents-plan-is-part-of-chinas-long-quest-to-become-theglobal-scientific-leader-145100.

${ }^{11}$ Elizabeth Redden, "Science on the Ballot," Inside Higher Ed, October 14, 2020, available at https://www.insidehighered.com/news/2020/10/14/look-stakes-science-presidentialelectionhttps://www.insidehighered.com/news/2020/10/14/look-stakes-science-presidential-election
} 
that innovation first and to scale."12 Others point out that, even if China benefits from these investments, "A major dilemma for the United States is that much of the proprietary technology being developed within American universities and which is being transferred to China, occurs in formats that do not break U.S. law, even if they may be counter to U.S. national interest." 13

The fundamental issues are not new: the pattern of an emerging economy trying to take advantage of technology and intellectual property investments elsewhere has a long global history. But the specifics of the case today are causing policy makers to address academic engagement with China with new attention. As Universities UK, the association of 139 British universities, explained in an October 2020 report (which never specifically mentions China), while foreign influence on the university sector is not new, what "has changed is the dynamism of the threat landscape and the centrality of universities, science and technology to the future security and prosperity of the UK." The report goes on to ground its concerns in values: "The risks to universities are not limited to the theft of intellectual property and data, or the security of university campuses. There are also threats to the values that have underpinned the success of the higher education sector: academic freedom, freedom of speech and institutional autonomy. These values are rooted in the UK's commitment to democracy and the rule of law." ${ }^{14}$

In recent years, various arms of the US government, including major funding agencies, have been voicing concerns and strengthening protections, even while continuing to emphasize the importance of basic scientific openness. An NIH advisory committee studied these issues several years ago and recommended steps to address "systematic programs to unduly influence and capitalize on U.S.-conducted research,"15 which have grown to be a clear priority of NIH's extramural research enterprise. ${ }^{16}$ The NSF has assessed foreign influence and security threats to the research enterprise, ${ }^{17}$ and it has created a research security office to protect against such threats. ${ }^{18} \mathrm{~A}$ bipartisan US Senate investigation last year found major shortcomings, recommending opportunities for funding agencies and counter-espionage organizations to

\footnotetext{
${ }^{12}$ Emily de La Bruyère and Nathan Picarsic, "Beijing's Innovation Strategy: Threat-Informed Acquisition for an Era of Great Power Competition," Proceedings of the Seventeenth Annual Acquisition Research Symposium, April 28, 2020, available at https://event.nps.edu/conf/app/researchsymposium/unsecured/dlprop/699/52.

${ }^{13}$ David Zweig and Siqin Kang, "America Challenges China's National Talent Programs," Occasional Paper Series (Center for Strategic \& International Studies (CSIS) Trustee Chair in Chinese Business \& Economics, May 5, 2020), https://csis-websiteprod.s3.amazonaws.com/s3fspublic/publication/20505 zweig AmericaChallenges v6 FINAL.pdf?bTLm4WdtG93IAVmxLdIWsgkgeNQDQUAv.

${ }^{14}$ Universities UK, "Managing Risks in Internationalisation: Security Related Issues," October 2020, https://www.universitiesuk.ac.uk/policy-and-analysis/reports/Documents/2020/managing-risks-in-internationalisation.pdf.

${ }^{15} \mathrm{NIH}$ Advisory Committee to the Director (ACD), "ACD Working Group for Foreign Influences on Research Integrity" (NIH Advisory Committee to the Director (ACD, December 2018), https://www.acd.od.nih.gov/documents/presentations/12132018Foreignlnfluences report.pdf.

${ }^{16}$ Mike Lauer, "Addressing Foreign Interference and Associated Risks to the Integrity of Biomedical Research, and How You Can Help," National Institutes of Health Office of Extramural Research, July 8, 2020, https://nexus.od.nih.gov/all/2020/07/08/addressingforeign-interference-and-associated-risks-to-the-integrity-of-biomedical-research-and-how-you-can-help/.

${ }^{17}$ Gordon Long, "Fundamental Research Security” (JASON Group, December 6, 2019), https://nsf.gov/news/special reports/jasonsecurity/JSR-19-2IFundamentalResearchSecurity 12062019FINAL.pdf.

${ }^{18}$ NSF, "NSF Creates New Research Security Chief Position," National Science Foundation, March 2, 2020, https://www.nsf.gov/news/news summ.jsp?cntn id=300086.
} 
strengthen their protections. ${ }^{19}$ And there is bipartisan Senate support for efforts to add some of these protections. ${ }^{20}$ The policy reaction may have been slow to develop but has become increasingly robust.

Today, US university leaders are taking unprecedented compliance steps regarding foreign influence and research security. The Association of American Universities has recommended steps its members can take to safeguard research security and reduce foreign influence. ${ }^{21}$ And, in a series of interviews conducted with more than 40 US university senior research officers in August through October, virtually every participant reported that they are devoting substantial and growing attention to these compliance issues. ${ }^{22}$ Indeed, a group of senior research officers reported its intention to increase university cooperation with federal law enforcement on these matters. ${ }^{23}$

These issues have come to light in other countries as well. The Universities UK report includes recommendations for universities focused on strengthening research security, as well as recommendations on partnership development, reputation management, research collaboration, and cybersecurity, among other topics. ${ }^{24}$ The German Rectors Conference recently issued guidelines specifically focused on academic sector cooperation with China, emphasizing academic freedom and other principles necessary to make partnerships mutually valuable. ${ }^{25}$ While some critics believe the concerns to be politicized, they are nevertheless arising broadly across a number of democratic and liberal countries. ${ }^{26}$

Thus far, notwithstanding these developments, US research funding agencies continue to position themselves as major advocates for open science. An NSF report concluded that "the

\footnotetext{
${ }^{19}$ United States Senate Permanent Subcommittee on Investigations Committee on Homeland Security and Governmental Affairs, Rob (Chairman) Portman, and Tom (Ranking Member) Carper, "Threats to the U.S. Research Enterprise: China's Talent Recruitment Plans," Staff Report, Securing the U.S. Research Enterprise from China's Talent Recruitment Plans (United States Senate Permanent Subcommittee on Investigations Committee on Homeland Security and Governmental Affairs, December 2019), https://www.hsgac.senate.gov/imo/media/doc/2019-11-18\%20PSI\%20Staff\%20Report\%20\%20China\%27s\%20Talent\%20Recruitment\%20Plans.pdf.

${ }^{20}$ Jeffrey Mervis, "Research Security Bill Advances in U.S. Senate Despite Opposition From Research Groups," Science, July 23, 2020, https://doi.org/10.1126/science.abd9824.

${ }^{21} \mathrm{AAU}$, "University Actions to Address Concerns about Security Threats and Undue Foreign Government Influence on Campus" (AAU, May 2020), https://www.aau.edu/sites/default/files/AAU-Files/Key-Issues/Science-Security/2020-Effective-Science-SecurityPractices-Summary.pdf.

${ }^{22}$ My colleague Oya Rieger and I will be publishing a full set of findings from this study later this year.

${ }^{23}$ Nidhi Subbaraman, "Universities Are Forging Ties with the FBI as US Cracks Down on Foreign Influence," Nature 579 (March 12, 2020): 331, https://doi.org/10.1038/d41586-020-00646-9.

${ }^{24}$ Universities UK, "Managing Risks in Internationalisation: Security Related Issues," October 2020, https://www.universitiesuk.ac.uk/policy-and-analysis/reports/Documents/2020/managing-risks-in-internationalisation.pdf.

${ }^{25}$ https://www.hrk.de/positionen/beschluss/detail/leitfragen-zur-hochschulkooperation-mit-der-volksrepublik-china/

${ }^{26}$ For a broad overview of European dynamics, see Éanna Kelly and Fintan Burke, "Universities wrestle with question of how open to be with China," Science Business, October 15, 2020, https://sciencebusiness.net/universities-wrestle-question-how-open-bechina.
} 
benefits of openness in research and of the inclusion of talented foreign researchers dictate against measures that would wall off particular areas of fundamental research."27

That same report expressed substantial concerns about a lack of reciprocity and a lack of transparency, especially with China's growing research ecosystem. The Senate investigation also picked up on reciprocity, mentioning a number of times a set of values that have been essential to the development of scientific excellence in the US, including "reciprocity, integrity, meritbased competition, and transparency," although it frequently describes "openness" as posing certain kinds of risk. ${ }^{28}$

In parallel, federal law enforcement agencies have launched numerous investigations, several resulting in arrests, alleging deceptive practices by applicants for US federal research funding. Specifically, they have targeted researchers who allegedly failed to disclose participation in or funding received from China's “Thousand Talents" program for recruiting research excellence from overseas. ${ }^{29}$ There have also been arrests targeting individuals alleged to have served surreptitiously in the Chinese military while working in US research labs, or for removing samples from US labs to bring to China. ${ }^{30}$ Indeed, some reports have suggested that the US government was motivated to close the Chinese consulate in Houston at least in part for these reasons, "accusing diplomats of aiding economic espionage and the attempted theft of scientific research." 31

Beyond the US, similar concerns appear to be arising in other liberal and democratic nations. For example, Australia recently withdrew visas of several visiting Chinese scholars, ${ }^{32}$ and its government will investigate Chinese influence in its university sector, including "technological and knowledge transfer from Australia that may be detrimental to our national interests." ${ }^{33}$ The Australian higher education sector is highly dependent on revenues from Chinese students,

\footnotetext{
${ }^{27}$ Gordon Long, "Fundamental Research Security" (JASON Group, December 6, 2019), https://nsf.gov/news/special reports/jasonsecurity/JSR-19-2IFundamentalResearchSecurity 12062019FINAL.pdf.

${ }^{28}$ United States Senate Permanent Subcommittee on Investigations Committee on Homeland Security and Governmental Affairs, Rob (Chairman) Portman, and Tom (Ranking Member) Carper, "Threats to the U.S. Research Enterprise: China's Talent Recruitment Plans," Staff Report, Securing the U.S. Research Enterprise from China's Talent Recruitment Plans (United States Senate Permanent Subcommittee on Investigations Committee on Homeland Security and Governmental Affairs, December 2019), https://www.hsgac.senate.gov/imo/media/doc/2019-11-18\%20PSI\%20Staff\%20Report\%20\%20China\%27s\%20Talent\%20Recruitment\%20Plans.pdf.

${ }^{29}$ Gina Kolata, "Vast Dragnet Targets Theft of Biomedical Secrets for China," The New York Times, November 4, 2019 , https://www.nytimes.com/2019/11/04/health/china-nih-scientists.html.

${ }^{30}$ Department of Justice Office of Public Affairs, "Harvard University Professor and Two Chinese Nationals Charged in Three Separate China Related Cases," The United States Department of Justice, January 28, 2020, https://www.justice.gov/opa/pr/harvard-university-professor-and-two-chinese-nationals-charged-three-separate-china-related.

${ }^{31}$ Edward Wong, Lara Jakes, and Steven Lee Myers, "U.S. Orders China to Close Houston Consulate, Citing Efforts to Steal Trade Secrets," The New York Times, July 22, 2020, https://www.nytimes.com/2020/07/22/world/asia/us-china-houston-consulate.html; Kate O'Keeffe and Aruna Viswanatha, "Chinese Diplomats Helped Military Scholars Visiting the U.S. Evade FBI Scrutiny, U.S. Says," The Wall Street Journal, August 25, 2020, https://www.wsj.com/articles/chinese-diplomats-helped-visiting-military-scholarsin-the-u-s-evade-fbi-scrutiny-u-s-says-11598379136.

32 John Ross, "Australia Cancels Chinese Scholars' Visas," Times Higher Education, September 9, 2020, https://www.timeshighereducation.com/news/australia-cancels-chinese-scholars-visas.

${ }^{33}$ John Ross, "Canberra Orders Probe Into ‘Foreign Interference' in Universities," Times Higher Education, August 31, 2020, https://www.timeshighereducation.com/news/australian-universities-face-new-scrutiny-not-scrutiny-they-wanted.
} 
making these developments all the more significant. Government authorities, scientific policymakers, and the higher education sector in other democratic and liberal countries will face similar dilemmas as they address the growing split.

\section{Impacts on Talent}

All this evidence of scientific uncertainty, wariness, and in some ways decoupling, seems likely only the beginning of a new era. If the geopolitical fracture with China deepens, elements of scientific openness, open science, and internationalization may be forced into retreat. In liberal and democratic countries, there are several implications that university leaders, and those who provide research support services, should be considering. One likely area of impact for higher education is in talent recruitment, where there are several areas of concern.

First, many institutions are highly dependent on revenues from international students. ${ }^{34}$ These institutions have traditionally "exported" higher education by bringing students to a campus, for example in the US, Australia, or the UK. During the disruption from the pandemic, it is clear that international student enrollments are falling off substantially. ${ }^{35}$ It also seems likely that enrollments from China, which represented a substantial share of the total international enrollments in US and Australian institutions, may never really recover.

Second, a substantial share of grant-funded science in the US is conducted by international graduate students, who comprise a substantial share of graduate students and postdocs in several important fields. It seems entirely possible that between changes to visa policies and an increasing focus on research security, talent recruitment from China will be especially disrupted. It may prove increasingly challenging to complete, or even compete for, a variety of projects if universities do not have the talent capacity to conduct the research. Doing so may require universities to substantially rethink talent recruitment for graduate students and postdoc researchers. ${ }^{36}$

In addition, China is said to have threatened that, should the US continue targeting members of its military who are conducting research in US labs, it will retaliate by targeting US citizens

\footnotetext{
${ }^{34}$ See for example Dick Startz, "Sealing the Border Could Block One of America's Crucial Exports: Education," Brown Center Chalkboard (Brookings, January 31, 2020), https://www.brookings.edu/blog/brown-center-chalkboard/2017/01/31/sealing-theborder-could-block-one-of-americas-crucial-exports-education/. and Brook Larmer, "One of America's Most Vital Exports, Education, Never Goes Abroad, but It Still Faces Threats," The New York Times Magazine, January 3, 2019,

https://www.nytimes.com/2019/01/03/magazine/one-of-americas-most-vital-exports-education-never-goes-abroad-but-it-still-facesthreats.html.

${ }^{35}$ Evidence of the US trend can be found here: National Student Clearinghouse Research Center, "First Look Fall 2020 Enrollment (As of Sept 10)," National Student Clearinghouse Research Center, September 24, 2020, https://nscresearchcenter.org/stayinformed/. International enrollments were already declining in the US before the pandemic for other reasons.

${ }^{36}$ Discussion of these issues in the US began well before the pandemic and its associated disruptions began, out of a concern about immigration restrictions and an attitude of inhospitality in the Trump administration. Andrea Widener, "Science in the US Is Built on Immigrants. Will They Keep Coming?," Chemical \& Engineering News (C\&en), Diversity, 97, no. 9 (March 4, 2019), https://cen.acs.org/careers/diversity/Science-US-built-immigrants-keep/97/i9.
} 
working in China. ${ }^{37}$ It is possible that this could have a real chilling effect on US citizens traveling to or working in China, potentially curtailing scientific collaborations.

Unfortunately, many of these issues could be compounded if geopolitical tension were also to lead to an increase in domestic racism. This is a special danger in immigrant societies, including several democracies, that have experienced backlash against immigration, and other forms of racism, in recent years. As academic leaders address some of the policy concerns of their governments, it will be especially important to avoid sliding into racial profiling or hostility against immigrants.

\section{Impacts on Communication and Infrastructure}

There has been a jump in concerns about services that enable personal or professional data to be shared with China-or, conversely, about influence operations that target democracies. While much of the focus has been on consumer services such as TikTok, there are also policy implications for research communication services and other scientific infrastructure.

Influence operations are a clear concern. It is believed that conference and journal infrastructure was used as a vector by Russian intelligence to influence the UK community. ${ }^{38}$ More recently, the FBI and the Cybersecurity and Information Security Agency (CISA) called for vigilance about "the potential threat posed by foreign-backed online journals that spread disinformation regarding the 2020 elections. "39 While some observers initially believed that this referred principally to low selectivity journals and preprint services as supposedly "soft targets," the payoff would presumably be greater by targeting high-quality journals. Even if the barriers are higher, it is clear that it is possible to direct inappropriate manuscripts into well-known journal brands. ${ }^{40}$ Publishers and editors of traditional journals and leaders of preprint and data services should be threat modeling these risks and considering how to build greater resilience in their processes.

Beyond process issues, we may see the development of corporate ownership questions. J ust as we have seen dramatic US government efforts to reshape the ownership of TikTok, ${ }^{41}$ so we may see questions about ownership of research infrastructure providers. For example, if a Chinese company were to attempt today to acquire an EU scientific publisher, as happened last year with

\footnotetext{
${ }^{37}$ Kate O'Keeffe and Aruna Viswanatha, "China Warns U.S. it May Detain Americans in Response to Prosecutions of Chinese Scholars," The Wall Street Journal, October 17, 2020, https://www.wsj.com/articles/china-warns-u-s-it-may-detain-americans-inresponse-to-prosecutions-of-chinese-scholars-11602960959

${ }^{38}$ Wikipedia, "Veruscript," Wikipedia, 2020, https://en.wikipedia.org/wiki/Veruscript.

${ }^{39} \mathrm{FBI}$ and CISA, "Public Service Announcement: Foreign Actors Likely to Use Online Journals to Spread Disinformation Regarding 2020 Elections" (Cybersecurity \& Infrastructure Security Agency (CISA), October 1, 2020), https://www.ic3.gov/Media/Y2020/PSA201001.

${ }^{40}$ Andrew Joseph, "Lancet, New England Journal Retract COVID-19 Studies, Including One That Raised Safety Concerns About Malaria Drugs," STAT News, June 4, 2020, https://www.statnews.com/2020/06/04/lancet-retracts-major-covid-19-paper-that-raisedsafety-concerns-about-malaria-drugs/. See also Roger C. Schonfeld, "Are Publishers Learning from Their Mistakes?" The Scholarly Kitchen, October 19, 2020, https://scholarlykitchen.sspnet.org/2020/10/19/are-publishers-learning/.

${ }^{41}$ Kate Cox, "Everything We Know So Far About Oracle Not Actually Buying TikTok," Ars Technica, September 21, 2020, https://arstechnica.com/tech-policy/2020/09/everything-we-know-so-far-about-oracle-not-actually-buying-tiktok/.
} 
France's EDP Sciences, ${ }^{42}$ it might be subject to questions about "technology sovereignty." 43 Whether the US government, EU, or other democracies would impose impediments to the acquisition of primary publishing businesses by Chinese firms is not yet known. But beyond primary publishing, other research infrastructure assets such as those focused on research data and personalized discovery might raise equal or perhaps even greater scrutiny.

Similarly, we may wonder what to expect in terms of Western publishing houses' sales into the Chinese STM market, ${ }^{44}$ which have been an important source of growth and have led some to tread lightly in response to Chinese censorship. ${ }^{45}$ As China pursues a variety of initiatives to develop its own research publishing sector, ${ }^{46}$ along with an associated scholarly evaluation infrastructure, ${ }^{47}$ it is possible that we will see a bifurcation between the Chinese research publishing sector and that of other major research countries.

\section{Impacts on Openness and Collaboration}

While there may be pressures against scientific openness and collaboration, this category is probably the area where we will see the least impact. Still, some impacts must be expected, and depending on how things develop geopolitically it is not impossible that the impacts here will increase.

In the first place, we should consider the chilling effects from government scrutiny of scientists. During the Cold War, counter-espionage efforts regularly affected academics and other scientists in a variety of fields. Today, as the FBI returns to campuses with a new kind of research security focus, we will see how this affects openness. At a minimum, it brings increased risk and uncertainty that will need to be addressed as universities consider various types of collaborations with Chinese universities and researchers.

Another area worth considering is the demand for reciprocity that we are seeing among US policy makers, including scientific funding agencies. Reciprocity is a powerful principle —one that we will likely see invoked more often in foreign affairs. In one way of thinking, these demands may bring "open science" itself under scrutiny. For example, if the open deposit of

\footnotetext{
42 Tao, "Guest Post — The Emergence of Chinese STM Publishers: Threat or Opportunity? An Interview with Matthias Wahls," The Scholarly Kitchen, November 19, 2019, https://scholarlykitchen.sspnet.org/2019/11/19/guest-post-the-emergence-of-chinese-stmpublishers-threat-or-opportunity-an-interview-with-matthias-wahls/.

${ }^{43}$ Éanna Kelly, "Technology Sovereignty: New EU Rules to Block Foreign Takeovers," Science Business, October 13, 2020, https://sciencebusiness.net/news/technology-sovereignty-new-eu-rules-block-foreign-takeovers.

44 Tao, "Guest Post — The Academic Market in China: An Overview," The Scholarly Kitchen, December 3, 2018, https://scholarlykitchen.sspnet.org/2018/12/03/guest-post-the-academic-market-in-china-an-overviewl.

${ }^{45}$ Kent Anderson, "The Walls Around Us - Why Cambridge University Press' Predicament Demands Attention," The Scholarly Kitchen, August 22, 2017, https://scholarlykitchen.sspnet.org/2017/08/22/blaming-victim-cambridge-university-press-predicamentdemands-attention/.

${ }^{46}$ Tao, "China Strives to Catch Up on STM Publishing: An Interview with Dr. Zong-Ming Cheng and Dr. Xiaofeng Wang," The Scholarly Kitchen, December 2, 2019, https://scholarlykitchen.sspnet.org/2019/12/02/china-strives-to-catch-up-on-stm-publishingan-interview-with-dr-zong-ming-chenq-and-dr-xiaofeng-wangl.

${ }^{47}$ Tao, "New Chinese Policy Could Reshape Global STM Publishing," The Scholarly Kitchen, February 27, 2020, https://scholarlykitchen.sspnet.org/2020/02/27/new-chinese-policy-could-reshape-global-stm-publishing/.
} 
datasets, methods, protocols and other materials does not soon become a global standard (and in particular one followed by Chinese scientists), will other countries' funding agencies continue to pursue an open science agenda? Or, is it possible that they will more narrowly instruct the scientists they fund to pursue reproducibility and replicability as a focused mandate, falling far short of open deposit of datasets, methods, and protocols? Or, might open access for certain materials be limited geographically-perhaps, ironically, not unlike the curious European proposal to "geowall" open access? 48 The calls for reciprocity being issued by US policy makers go far beyond datasets and could cut at the growing movement for open science.

Looking ahead, the US government could expand its use of various kinds of sensitive-butunclassified designations, for example the "Export Controlled Research" category, for some kinds of science. ${ }^{49}$ This could affect publishing, conference presentations, international research collaborations, and technology transfer, in a variety of ways.

The perceived imbalance in funding for basic research may represent a tricky dilemma. Basic research is funded by governments precisely because it has been seen as a public good. Perhaps it is possible for funding organizations across democratic governments and other major scientific economies such as China to reassess their comparative levels of investment. It is also possible to imagine the funding agencies of democratic and liberal countries electing simply to reduce their investment and instead focus more of their resources on applied categories of research, although this would be troubling to innovation in the long run.

There remains a real possibility that few if any of these effects will be seen broadly. In a best case scenario, we can probably expect to see enhanced scrutiny focused in fields such as AI, advanced materials, and quantum computing, accompanied by continued or even expanded global collaboration in other research areas, such as climate change and biodiversity. But, it is also possible that, should an even deeper geopolitical split develop, there could be more significant implications for the scientific enterprise.

\section{A Renewal of Openness}

While there are substantial reasons to believe that scientific openness could be reduced as a result of the growing geopolitical split, it will not be eliminated altogether. Indeed, while acknowledging the risks, we should also allow for some forms of renewal of scientific openness.

The COVID pandemic may in certain ways be instructive. For all the reported transparency challenges during certain phases of the COVID epidemic, scientific openness drove substantial information sharing as measured through networks of citation. This surely contributed to the

\footnotetext{
${ }^{48}$ Lisa Janicke Hinchliffe, "Can Geowalling Save Open Access?," The Scholarly Kitchen, November 14, 2019, https://scholarlykitchen.sspnet.org/2019/11/14/can-geowalling-save-open-access/.

${ }^{49}$ For an overview of some of these issues from the perspective of the academic sector, see https://www.aau.edu/issues/exportcontrols.
} 
development of treatments and vaccines. At the same time, there was apparently less international scientific collaboration within projects than some may have anticipated. ${ }^{50}$

Looking further in the past, it is important to underscore that, even during a geopolitical split as extreme as the Cold War, there never was a complete decoupling between scientists from the two blocs. There were open exchanges of various sorts, as well as efforts by each side to benefit, licitly and otherwise, from the discoveries of the other. There were also substantial efforts by the West to use scientific openness to establish the benefits of a broader open society. ${ }^{51}$

Looking ahead, we may expect scientific policy to be considered by western and liberal governments as a component of foreign policy, potentially in the service of a kind of "soft power" diplomacy. J ust as some have believed that trade and economic development could reduce the risk of conflict with China, so it could be that scientific collaborations will be seen to advance this objective.

Finally, we may also find the university sector in democratic and liberal countries to resist some of the pressures they can expect to face as a result of the growing split with China. Indeed, university leaders may find themselves reflecting on the various challenges to scientific openness beyond China, for example in the growth of research sponsored by the corporate sector that is sometimes therefore unable to be shared broadly. While resisting any of these trends may not be possible, we could imagine university leaders electing to champion not only academic freedom but also anti-racism and scientific openness as values that they hold dear.

\section{In Sum}

While the split with China continues to develop, some of its geopolitical dynamics are still emerging. In particular, the question of whether a variety of separate countries with differentiated interests will align to resist China, and if so how, is by no means settled. Whether they will develop aligned policies around scientific collaboration is therefore largely unclear, and in any case there is little reason to anticipate a complete decoupling.

Even so, uncertainty has increased substantially in recent years. As a result, scientific organizations, including universities, policy makers, learned societies, publishers, and other facilitators of collaboration, should be planning for a policy environment informed by the risks of a growing split. Both scientific collaborations and research strategies, as well as the business strategies and public policies that enable scientific collaboration and communication, should account for the attendant risks - and opportunities.

\footnotetext{
${ }^{50}$ Science, Digital, Daniel Hook, and Simon Porter. "How COVID-19 Is Changing Research Culture". Digital Science, June 4, 2020. https://doi.org/10.6084/m9.figshare.12383267.v2.

${ }^{51}$ See for example Audra J. Wolfe, Freedom's Laboratory: The Cold War Struggle for the Soul of Science (John Hopkins University Press, 2018) and Gerson S. Sher, "Science Knows Boundaries: Reflections on Sixty Years of U.S.-Former Soviet Union Scientific Cooperation," Science \& Diplomacy, December 2019, https://www.sciencediplomacy.org/article/2019/science-knows-boundariesreflections-sixty-years-us-former-soviet-union-scientific.
} 